\title{
What sort of teenager has low intakes of energy nutrients?
}

\author{
BY DAVID R. WOODWARD \\ Biochemistry Department, University of Tasmania, G.P.O. Box 252C, Hobart, \\ Tasmania 7001, Australia
}

(Received 10 July 1984-Accepted 1 November 1984)

1. An alternative statistical technique, based on analysis of the 25 th percentile, was used to examine teenagers' diets. The technique was developed to identify personal characteristics that affected the prevalence of low energy and nutrient intakes. It provided useful information not obtainable from methods based on average intakes.

2. The study sample was a representative sample of 1055 high-school students in Tasmania, Australia, aged $11-16$ years.

3. Among girls, different characteristics had the greatest influence on the prevalence of low intakes ('low' being defined as below the 25 th percentile for girls). Fatness had the greatest influence for several dietary components. Fatter girls were more likely to have low intakes of energy, carbohydrate, iron, calcium and niacin-equivalent, and also of 'empty-energy' foods. School type had the greatest influence for fat, riboflavin and vitamin A. Exercise had the greatest influence for protein, low intakes being more usual among the least active girls.

4. Among boys, height and age generally had the greatest influence on the prevalence of low intakes ('low' being defined as below the 25 th percentile for boys). Taller and older boys were less likely to have low intakes. This was attributed partly to increased physiological needs, but peer-group influences appeared more important in relation to food choices. Thiamin was unusual, in that recent use of analgesics had the greatest influence on the prevalence of low intakes.

Information on dietary variation within communities could be very useful to epidemiologists, nutrition educators and clincians. However, only a handful of published studies have examined how dietary intakes are influenced by various personal characteristics in western societies (Samuelson et al. 1971; Cook et al. 1973).

In a previous paper (Woodward, 1984) such an analysis was undertaken, based on information from a survey of Tasmanian high-school students. That analysis focussed on average intakes, using the median as the indicator of average intakes.

While the average is a familiar and convenient indicator of the intakes of a group, it may fail to detect important differences between groups. Consider, for instance, the energy intakes, in MJ, of two hypothetical groups. Values for group A were 1, 2, 10, 19, 20; those for group B were 9, 9, 10,11,11. 'On average', the two groups had the same level of intakes, having the same median and the same mean. The groups, however, also showed clear differences. Both over- and undernutrition appeared to be more prevalent in group A. This finding could be of considerable interest, but would not be brought out by a simple comparison of averages.

Analysis of this Tasmanian survey was therefore not restricted to average intakes. The present paper looks at influences operating at the 25 th percentile of intakes. This percentile, the average of those with below-average intakes, is a logical indicator of intakes at the lower end of the spectrum. If we define intakes below the 25 th percentile as 'low', by the standards of the population in question, the analyses reported here tell us what sort of teenagers were more likely to have low intakes. 


\section{MATERIALS AND METHODS}

Students in grades 7-10 (modal ages 12-15 years) in Tasmanian high schools were sampled by a two-stage cluster technique. Subjects completed a $24 \mathrm{~h}$ dietary record (Woodward et al. 1981) and a questionnaire on personal characteristics (Woodward, 1984). In all, 1055 students provided usable replies, a response rate of $81 \%$. As far as could be ascertained, the respondents were representative of Tasmanian high school students, and energy and nutrient intakes were consistent with those reported in other Australian surveys.

The personal characteristics studied were of three types, physical (sex, age, height, weight, fatness), behavioural (exercise-level and usage of alcohol, cigarettes, analgesics and vitamin-supplements) and socio-economic (school type, educational level of each parent, social status, family size). For the statistical analysis, each of these characteristics was re-expressed as one or more explanatory variables, (EV). For instance, the characteristic weight yielded two explanatory variables, the EV W1 (which compared the lightest third of the group with the heavier two thirds) and the EV W2 (which compared the heaviest third of the group with the others). A full list of the EV examined in the present study is given in Table 1 of Woodward (1984).

In the previous paper (Woodward, 1984), the analysis was based on assessing the impact of each explanatory variable on median intakes. In the present paper, analysis was based on assessing the impact of each EV on the 25 th percentile of intakes. Calculation of impacts on the 25th percentile used the same method (the 'median test') as was used for impacts on the median, with one difference: the term ' 25 th percentile' was substituted for 'median' throughout. (The statistical rationale for this modification is provided in Conover (1971).)

Using this criterion of impact, the analysis developed, for each nutrient, a hierarchial model of influences operating at the 25 th percentile of intakes. The analysis followed the approach previously applied to median intakes in Woodward (1984), and is perhaps best explained by the example of energy intakes.

The impact of each of the thirty-nine EV on the 25th percentile of energy was assessed. The EV with greatest impact was sex, and for further analysis the sample was divided into boys and girls. Among girls, the EV with greatest impact was the contrast between plump and other girls (F2), and the girls were divided into plump and not-plump for further analysis. Among boys, the contrast between short and not-short boys (H1) was the 'dominant' EV, i.e. had the greatest impact; the boys were therefore divided into short and not-short for further analysis. This yielded four ' distinctive groups': plump girls, not-plump girls, short boys, not-short boys. The process of identifying dominant EV and subsequent sub-division was continued until distinctive groups were defined in which no EV had a significant impact or in which there were fewer than twenty persons.

As in the previous paper (Woodward, 1984), statistical impacts are characterized as moderate $(0.001<P<0.01)$, strong $(0.0001<P<0.001)$ or very strong $(P<0.001)$.

For some analyses, foods were grouped into five categories, which are defined in detail in Woodward (1984). These were:

Cereal. This included 'plain' cereals, such as bread, low-sucrose breakfast cereals, plain biscuits and scones; it also included butter and margarine spread thereon. Cereal products with substantial amounts of sucrose, such as cakes and puddings, were excluded. The 25 th percentile of cereal intakes was 1.7 MJ for boys and 1.1 MJ for girls.

Fruit and vegetable. This included all such foods and their juices, except maize and dried legumes; jams and fruit pies were excluded. Intakes were 0.9 and $0.8 \mathrm{MJ}$ for boys and girls respectively.

Meat. This included all muscle and organ tissue of vertebrate and invertebrate origin, as well as eggs, nuts and legumes; pies and stews based on these were also included. Intakes were $1.5 \mathrm{MJ}$ for boys and 1.1 MJ for girls. 
Table 1. The 25th percentile of energy and nutrient intakes among girls in Tasmanian high schools

(Thin and plump girls each comprised $33 \%$ of the girls in our sample; $12 \%$ exercised less than $0.5 \mathrm{~h} / \mathrm{d}$, $26 \%$ attended non-government schools and $9 \%$ attended 'private' (non-catholic, non-government) schools. Where an explanatory variable (EV) appears in parentheses, it was dominant for that substance in that distinctive group)

\begin{tabular}{|c|c|c|c|c|}
\hline & \multirow{2}{*}{$\begin{array}{l}\text { Dominant } \\
\mathrm{EV}\end{array}$} & \multicolumn{3}{|c|}{25 th percentile of intakes among } \\
\hline & & Girls & \multicolumn{2}{|c|}{ Distinctive groups of girls } \\
\hline Thiamin (mg) & None & $1 \cdot 0$ & - & - \\
\hline Iron (mg) & $\mathrm{F} 1 * *$ & $9 \cdot 2$ & $\begin{array}{l}\text { Thin } \\
10 \cdot 0\end{array}$ & $\begin{array}{l}\text { Not thin } \\
8.6\end{array}$ \\
\hline & & & Not plump & Plump \\
\hline Energy (MJ) & $\mathrm{F} 2^{* *}$ & 6.9 & $7 \cdot 4$ & $5 \cdot 9$ \\
\hline Carbohydrate (g) & $\mathbf{F} 2^{*}$ & 198 & $210\left(\mathrm{SMl}^{*}\right)$ & 165 \\
\hline Calcium $(\mathrm{g})$ & $\mathrm{F} 2^{* *}$ & 0.46 & $0.51\left(\mathrm{~A} 1^{*}\right)$ & $0.38\left(\mathrm{SS} 1^{*}\right)$ \\
\hline Niacin-equivalent (mg) & $\mathrm{F} 2 *$ & 21 & $23\left(\mathrm{Al}^{*}\right)$ & 18 \\
\hline Protein $(\mathrm{g})$ & $\mathrm{EX} 1^{*}$ & 52 & $\begin{array}{l}\text { Active } \\
55\end{array}$ & $\begin{array}{l}\text { Inactive } \\
45\end{array}$ \\
\hline $\begin{array}{l}\text { Riboflavin (mg) } \\
\text { Vitamin A (mg) }\end{array}$ & $\begin{array}{l}\text { ST3* } \\
\text { ST3** }\end{array}$ & $\begin{array}{l}1 \cdot 5 \\
0 \cdot 58\end{array}$ & $\begin{array}{l}\text { Non-government schools } \\
1.6\left(\mathrm{AN} 1^{*}\right) \\
0.70\end{array}$ & $\begin{array}{l}\text { Government schools } \\
\quad 1.4 \\
0.54\left(\mathrm{EX}^{*}\right)\end{array}$ \\
\hline Fat (g) & ST5* & 69 & $\begin{array}{l}\text { 'Private' schools } \\
79\end{array}$ & $\begin{array}{l}\text { Other schools } \\
68\left(\mathrm{~F} 2^{* *}\right)\end{array}$ \\
\hline
\end{tabular}

$\mathrm{F} 1$, fatness $<18.5 \mathrm{~kg} / \mathrm{m}^{2} v$. The rest; $\mathrm{F} 2$, fatness $>20.7 \mathrm{~kg} / \mathrm{m}^{2} v$, the rest; ST3, government schools $v$. non-government schools; ST5, 'private' (non-catholic, non-government) schools $v$. other schools; SM1, have never smoked $v$. the rest; A1, $\leqslant 12$ years $v .>13$ years; AN1, consumed an analgesic in the previous week $v$. the rest; SS1, professional-managerial households $v$. the rest.

Level of impact of EV: ${ }^{*} 0.001<P<0.01,{ }^{* *} 0.0001<P<0.001$.

Dairy. This included milk, cheese and yoghurt; ice-cream and butter were excluded. Intakes were $0.8 \mathrm{MJ}$ for boys and $0.4 \mathrm{MJ}$ for girls.

Miscellaneous. This included all items not in the other four categories. Major items were 'sweet' cereals, confectionery and soft drinks, soups and sauces, alcohol, proprietary lines of the Milo (malted beverage) and Vegemite (yeast extract) type. Intakes were 1.3 MJ for boys and $1 \cdot 1 \mathrm{MJ}$ for girls.

\section{RESULTS}

As with the analysis of median intakes (Woodward, 1984), vitamin C was atypical. None of the thirty-nine $\mathrm{EV}$ studied had a significant $(P<0.01)$ impact on the 25 th percentile of vitamin $\mathrm{C}$ intakes in the whole sample, and therefore no further analysis of influences on vitamin $\mathrm{C}$ intakes was undertaken.

\section{Low intakes were more common among girls}

For the 25th percentile of intakes of energy and the other nutrients, the EV sex was consistently dominant, with a very strong impact. The 25 th percentile values for boys were higher than those for girls. If we define values below the 25 th percentile as 'low', then we may express this finding by saying that girls were more likely to have low intakes.

To elucidate food choices underlying these sex differences, it was decided to examine the impact of the EV sex on the 25th percentile of five major food categories, defined on pp. 242-243. The impact of sex was very strong for the cereal, meat, and dairy categories, with 
boys being less likely to have low intakes. However, sex did not have a significant impact on fruits and vegetables or miscellaneous foods. Thus, girls were more likely to have low intakes of energy and nutrients because they were more likely to have low cereal, meat and dairy intakes.

\section{Among girls, fatness or school type was usually dominant}

As shown in Table 1, fatness-based EV were dominant for Fe, energy, carbohydrate, $\mathrm{Ca}$ and niacin-equivalent. Intakes of miscellaneous foods were strongly influenced by fatnessbased EV, both F1 (thin $v$. others) and F2 (plump $v$. others); low intakes were more prevalent with increasing fatness.

Among not-plump girls, an EV based on smoking was dominant for carbohydrate, and one based on age for $\mathrm{Ca}$ and niacin-equivalent. Neither of these $\mathrm{EV}$ had a significant impact on any food category. Among the not-plump girls, those who had never smoked $(40 \%$ of the group) had a 25th percentile of $225 \mathrm{~g}$ for carbohydrate, compared with $197 \mathrm{~g}$ for the remainder. Those aged 12 years or less ( $25 \%$ of these girls) had values of $0.38 \mathrm{~g}$ for $\mathrm{Ca}$ and $20 \mathrm{mg}$ for niacin-equivalent, compared with $0.54 \mathrm{~g}$ and $25 \mathrm{mg}$ for the rest.

Among plump giris, an EV based on social status was dominant for Ca but did not affect any food category. Those from professional-managerial households ( $28 \%$ of plump girls) had a 25 th percentile for $\mathrm{Ca}$ of $0.60 \mathrm{~g}$, compared with $0.33 \mathrm{~g}$ for others.

An EV based on exercise was dominant for protein, but did not have a significant impact on any food category.

EV based on school type were dominant for three nutrients. The EV ST3 (government v. non-government schools) affected riboflavin and vitamin A intakes, and also had a moderate impact on cereal intakes. The EV ST5 ('private' (i.e. non-catholic, non-government) schools $v$. other schools) affected fat intakes, but not any of the food categories. For girls in particular school types, dominant EV were identified for riboflavin, vitamin A and fat.

In non-government schools, an EV based on analgesic consumption was dominant for riboflavin, but did not influence any food category. Low riboflavin intakes were more common among the $53 \%$ of these girls who had not used an analgesic in the previous week; the 25th percentile values were $1.9 \mathrm{mg}$ for users and $1.5 \mathrm{mg}$ for non-users.

In government schools, an EV based on exercise was dominant for vitamin A but did not influence any food category. Low vitamin A intakes were more common among the least active (13\% of the group): the 25 th percentile values were $0.41 \mathrm{mg}$ for the least active and $0.57 \mathrm{mg}$ for the remainder.

Among girls attending catholic and government schools, an EV based on fatness was dominant for fat intakes, and had a strong impact on intakes of the miscellaneous food category. The plumpest third of these girls had a 25 th percentile value of $61 \mathrm{~g}$ for fat, compared with $72 \mathrm{~g}$ among the remainder of these girls. The EV F2 had a parallel, strong impact on the miscellaneous food category, with low intakes being more prevalent among the plumpest girls.

\section{Among boys, height- or age-based EV were usually dominant}

As shown in Table 2, an EV based on age was dominant for several nutrients: fat, $\mathrm{Fe}$, riboflavin, niacin-equivalent and vitamin $\mathrm{A}$. It had a strong impact on the 25th percentile of meat intakes and a moderate impact on cereals and on fruits and vegetables. Younger boys were more likely to have low intakes of these nutrients and foods.

Among boys aged $\leqslant 12$ years, an EV based on school type was dominant for $\mathrm{Fe}$ and vitamin A but had no impact on any food category. The 25 th percentile value for boys attending catholic schools (16\% of these younger boys) was $9.8 \mathrm{mg}$ for $\mathrm{Fe}$ and $0.50 \mathrm{mg}$ for vitamin A, compared with 11.3 and $0.66 \mathrm{mg}$ for younger boys at other schools. 
Table 2. The 25th percentile of energy and nutrient intakes among boys in Tasmanian high schools

(Boys aged $\leqslant 12$ years comprised $25 \%$ of boys; $33 \%$ were short and $34 \%$ had consumed an analgesic in the preceding week. Where an explanatory variable (EV) appears in parentheses, it was dominant for that substance in that distinctive group)

\begin{tabular}{|c|c|c|c|c|}
\hline & \multirow{2}{*}{$\begin{array}{l}\text { Dominant } \\
\text { EV }\end{array}$} & \multicolumn{3}{|c|}{25 th percentile of intakes among } \\
\hline & & Boys & Distinctiv & boys \\
\hline \multirow[t]{2}{*}{ Calcium (g) } & None & $0 \cdot 60$ & - & - \\
\hline & & & $\leqslant 12$ years & $\geqslant 13$ years \\
\hline Fat $(g)$ & $\mathrm{A} 1 * * *$ & 88 & 76 & 95 \\
\hline Iron (mg) & $\mathrm{A} 1^{*}$ & $11 \cdot 8$ & $11 \cdot 0\left(\mathrm{ST} 4^{*}\right)$ & $12 \cdot 3\left(\mathrm{ST}^{*}\right)$ \\
\hline Riboflavin (mg) & $\mathrm{Al} 1^{* *}$ & $2 \cdot 0$ & 1.6 & $2 \cdot 2$ \\
\hline Niacin-equivalent (mg) & $\mathrm{A} 1 * *$ & 27 & 24 & 29 \\
\hline Vitamin A (mg) & $\mathrm{A} 1 * *$ & 0.76 & $0.63\left(\mathrm{ST}^{*}{ }^{*}\right)$ & $0.80\left(\mathrm{~A}^{*}\right)$ \\
\hline & & & Short boys & Other boys \\
\hline Energy (MJ) & $\mathrm{H} 1 * * *$ & $8 \cdot 8$ & 8.0 & $9 \cdot 5$ \\
\hline Protein $(g)$ & $\mathrm{H} 1^{*}$ & 70 & 65 & 75 \\
\hline Carbohydrate (g) & $\mathrm{H} 1 * *$ & 258 & $235\left(\mathrm{~F} 1^{*}\right)$ & 279 \\
\hline Thiamin (mg) & AN1* & $1 \cdot 35$ & $\begin{array}{l}\text { Used analgesics } \\
1-21\end{array}$ & $\begin{array}{l}\text { Other boys } \\
1.42\left(\mathrm{~A} 1^{*}\right)\end{array}$ \\
\hline
\end{tabular}

$\mathrm{A} 1, \leqslant 12$ years $v,>13$ years; $\mathrm{H} 1, \leqslant 1.57 \mathrm{~m} v$. the rest; $\mathrm{AN} 1$, consumed an analgesic in the previous week $v$. the rest; ST4, catholic schools $v$. the rest, F1, fatness $<17.3 \mathrm{~kg} / \mathrm{m}^{2} v$. the rest; ST3, government schools $v$. the rest $\mathrm{A} 2, \leqslant 13$ years $v .>14$ years.

Level of impact of EV: ${ }^{*} 0.001<P<0.01,{ }^{* *} 0.0001<P<0.001, * * * P<0.0001$.

Among boys aged $>13$ years, an EV based on school type was dominant for $\mathrm{Fe}$, and one based on age for vitamin A; neither of these EV affected intakes of any food category. The 25th percentile for $\mathrm{Fe}$ among older boys at non-government schools ( $33 \%$ of the older boys) was $13.7 \mathrm{mg}$ compared with $11.8 \mathrm{mg}$ for older boys at government schools. The vitamin A value for 13 -year-old boys (32\% of the older boys) was $0.75 \mathrm{mg}$ compared with $0.85 \mathrm{mg}$ among those aged $>14$ years.

An EV based on height was dominant for energy, protein and carbohydrate, with low intakes being more common among short boys; however, it did not have a significant impact on any food category.

Among short boys, an EV based on fatness was dominant for carbohydrate but had no effect on any food category. The thinnest third of short boys (Quetelet index $<17.3 \mathrm{~kg} / \mathrm{m}^{2}$ ) had a 25 th percentile value of $261 \mathrm{~g}$ for carbohydrate, compared with $216 \mathrm{~g}$ for their less thin counterparts.

An EV based on analgesic consumption was dominant for thiamin but did not affect any food category. Among the boys who had not used analgesics in the last week, an EV based on age was dominant, and also showed a moderate impact on the dairy and fruit and vegetable categories; younger boys were more likely to have low intakes. The younger non-users ( $22 \%$ of the non-users) had a 25 th percentile of $1.17 \mathrm{mg}$ for thiamin, compared with $1.47 \mathrm{mg}$ for the rest of the non-users. 


\section{DISCUSSION}

Other dietary surveys have used the 25 th percentile as a method of summarizing information on dietary intakes (Samuelson, 1971; van Schaik \& Kenter, 1973; United States National Center for Health Statistics, 1979; Darke et al. 1980). It is easily calculated and has a clear and unambiguous meaning: only $25 \%$ of sample members have values below the 25 th percentile. An alternative but equivalent interpretation is that the 25 th percentile is the average of those with below-average intakes. Those with intakes below the 25 th percentile may be regarded as having intakes that are low by the standards of the population in question, although not necessarily low in relation to physiological requirements.

The present paper has used the 25 th percentile not simply as a summarizing statistic. It has ventured into unfamiliar territory by using it as the target for detailed statistical analysis. This analysis aimed to identify those personal characteristics that had greatest influence, in statistical terms, on the 25 th percentile of energy and nutrient intakes (or, in equivalent terms, had greatest influence on the prevalence of low energy and nutrient intakes). This approach, while unusual, is conceptually a simple extention of the median-based hierarchial modelling process used previously (Woodward, 1984). By use of this approach, we may identify the sort of person who is more likely to have low intakes. Such information has value for the clinician, the educator and the epidemiologist.

\section{Adequacy of intakes}

For an initial assessment of dietary adequacy, the 25 th percentiles were compared with the official Australian 'recommended daily allowances' for boys and girls aged 11-15 years (National Health and Medical Research Council, 1971). These values have a fair safety margin but provide a first estimate of requirements for use in survey assessment.

For both sexes, the 25 th percentile of energy intakes was well below the recommended level: for girls, the observed values was $6.9 \mathrm{MJ}$ (recommended value $10.4 \mathrm{MJ}$ ); for boys $8 \cdot 8 \mathrm{MJ}$ (recommended value $12 \cdot 2 \mathrm{MJ}$ ). It has been suggested that the current recommendations are inappropriately high in relation to current levels of physical activity among children (Hitchcock \& Gracey, 1980).

Among girls, the 25 th percentile was below the recommendation for three nutrients: $\mathrm{Ca}$ $(0.46 \mathrm{~g} \mathrm{v} .0 .6 \mathrm{~g}), \mathrm{Fe}(9.2 \mathrm{mg} v .12 \mathrm{mg})$, vitamin A $(0.58 \mathrm{mg} v .0 .725 \mathrm{mg})$. These may therefore be considered the more vulnerable nutrients among girls.

Among boys, none of the nutrients had a 25 th percentile below the recommended level.

\section{Effect of fatness among girls}

Fatter girls were more likely to have low intakes of energy, carbohydrate, $\mathrm{Fe}, \mathrm{Ca}$, niacin-equivalent and (if they were not attending non-catholic, private schools) fat. They were also more likely to have low intakes of 'miscellaneous' foods, such as confectionery, ice-cream, soft drinks and sweetened cereals.

Interpretation must be cautious. The fatness categories used were based on self-reported height and weight, and the survey was cross-sectional, with no information on past body size or diet. Nevertheless, it seems not unreasonable to interpret the results as suggesting a longitudinal trend. On that interpretation, as teenage girls assumed a more adult shape, they were more likely to restrict intakes of these foods, with a consequent increase in the prevalence of low intakes of energy and certain nutrients.

Restriction of these 'miscellaneous' foods should lead to lower energy, sucrose and fat intakes. Such a dietary adjustment would be considered sensible by most nutritionists, especially if the subject were concerned about obesity. The results reported in this paper, however, indicate that the restriction of these foods also led to a greater prevalence of low 
$\mathrm{Fe}$ and $\mathrm{Ca}$ intakes. Intakes of these minerals were fairly precarious among girls as a whole, and were even more precarious among the plumper girls.

It would appear that the 'miscellaneous' foods made a useful contribution to $\mathrm{Fe}$ and $\mathrm{Ca}$ intakes among girls. This result has clear implications for counselling and nutrition education in this age-group among girls. Negative advice to reduce intakes of 'empty-energy' foods must be balanced by positive advice to maintain or increase intakes of foods rich in $\mathrm{Fe}$ and $\mathrm{Ca}$.

\section{Effect of school type among girls}

Girls at government schools were more likely to have low intakes of riboflavin and vitamin A and low intakes of cereals. (Cereals are an important source of riboflavin in Australia (Australian Bureau of Statistics, 1983)). The vitamin A content of the cereal category was due to the inclusion in this category of the butter and margarine spread on bread.) For vitamin $\mathrm{A}$, the 25 th percentile was below the recommendation in both school types. The biological significance of this 'deficiency' is hard to assess, since the body may have substantial reserves of vitamin A and day-to-day variations in vitamin A intakes are quite marked (Beaton et al. 1983). Nevertheless, it would seem that more emphasis on foods rich in vitamin A is desirable in nutrition education, especially in government schools.

Girls at 'private' schools were less likely to have low fat intakes. There is as yet no quantitative Australian recommendation on fat intakes, but epidemiological evidence suggests that high fat intakes may lead to an increased risk of some types of cancer (Palmer $\&$ Bakshi 1983). Some authors suggest that adolescent dietary habits persist into adulthood (Ohlson \& Harper, 1976). If so studies of women with 'private' school background might be useful in following these postulated links. (Non-Australian readers should note that students at these 'private' schools tend to come from relatively wealthy households with fairly conservative attitudes.)

\section{Effect of height and age among boys}

As boys became older or taller, they were less likely to restrict their intakes. Height and age were fairly closely linked. Both presumably reflected the adolescent growth spurt, with its attendant increase in physiological requirements.

A more detailed examination revealed that both age and height had a significant impact on energy and most nutrients, the dominant EV being sometimes age-based and sometimes height-based. Age had a significant impact on three food categories, but height did not affect the intakes of any food category at the 25 th percentile. This discrepancy was puzzling: why should height influence intakes of energy and nutrients, but not of food categories?

In Tasmanian schools, students are allocated to grades on the basis of age, and a given grade will consist of students with an age-range of only about 12 months. The wide variation in growth rate in early adolescence means that boys in a single grade, while similar in age, may vary markedly in height. Thus, in this age range, it is reasonable to treat height as an index of physical maturation and age as an index of peer-group pressures.

On this interpretation, the changes in energy and nutrient intakes as boys become older and taller could be attributed, in part, to increased physiological requirements. The shifts in food choice appeared, however, to be due mainly to peer group influences. As most individuals make their dietary decisions at the food-choice level rather than at the nutrient-choice level, the importance of peer group influences on food choices is a finding with considerable relevance to nutrition education and counselling.

\section{Other influences}

Various other influences are noted in Tables 1 and 2. Girls who were least active were more likely to restrict protein intakes. Did this reflect a more general apathy about health-related 
Table 3. Characteristics with greatest impact on the 25th and 50th percentiles of energy and nutrient intakes among Tasmanian high schools

\begin{tabular}{|c|c|c|c|c|}
\hline \multirow[b]{2}{*}{ Percentile... } & \multicolumn{2}{|c|}{ Girls } & \multicolumn{2}{|c|}{ Boys } \\
\hline & 25 th & 50 th & 25 th & 50th \\
\hline Energy & Fatness & & Height & Age \\
\hline Protein & Exercise & & Height & Age \\
\hline Fat & School-type & Fatness & Age & Age \\
\hline Carbohydrate & Fatness & & Height & Age \\
\hline Iron & Fatness & Fatness & Age & Age \\
\hline Calcium & Fatness & $\begin{array}{l}\text { Vitamin- } \\
\text { usage }\end{array}$ & & Age \\
\hline Thiamin & & Weight & Analgesics & Height \\
\hline Riboflavin & School-type & Family-size & Age & Age \\
\hline Niacin-equivalent & Fatness & Weight & Age & Height \\
\hline Vitamin A & School-type & $\begin{array}{l}\text { Mother's } \\
\text { education }\end{array}$ & Age & Age \\
\hline
\end{tabular}

behaviour in at least a subgroup of girls? Boys who had recently used analgesics were more likely to have low thiamin intakes. Such boys might have had depressed appetites because of recent illness, but why did this effect show up only with thiamin? These effects may, of course, merely be statistical 'flukes', but it might be of interest to follow them up in other populations.

\section{The usefulness of analysing the 25 th percentile}

A previous study (Woodward, 1984) explored influences operating at the median, i.e. at the middle of the spectrum of intakes. The present paper has focussed on influences operating at the 25 th percentile, i.e. towards the lower end of the spectrum.

Has this analysis provided useful information not obtainable from the earlier analysis? Examination of Table 3 indicates that for a given substance the 25 th and 50 th percentiles among boys were usually subject to the same influences or to closely-related influences. However, the 25 th and 50 th percentiles for a given substance among girls rarely agreed; generally, the dominant influences for the two percentiles were unrelated, or only one of the two percentiles was subject to any significant influence.

Some of the discrepancies between the 25 th and 50th percentiles have clinical and educational relevance. For example, analysis based on the median implied that energy and $\mathrm{Ca}$ intakes among girls were not influenced by fatness; the analysis based on the 25 th percentile revealed that fatter girls were more likely to restrict their energy and Ca intakes. The latter finding suggests rather different clinical and educational strategies from the former. Similarly, the 25 th percentile analysis showed differences between schooltypes in intakes of fat, riboflavin and vitamin $\mathbf{A}$ - differences not exposed by median-based analysis.

Dietary surveys can provide much useful information for the clinician involved in preventive medicine, the epidemiologist and the nutrition educator. It is desirable to analyse the information from such surveys thoroughly, rather than rely on the use of one or two traditional statistical methods, applied in possibly inappropriate ways. The use of percentilebased analyses, such as those applied in the present paper, offers a statistically valid approach to a more comprehensive analysis of such surveys.

The author acknowledges with gratitude the patient and skilled computer programming of Steven Andrewartha, and useful discussions with Glen McPherson. Financial support was provided by the University of Tasmania and the National Health and Medical Research Council of Australia. 


\section{REFEREN CES}

Australian Bureau of Statistics (1983). Apparent Consumption of Food and Nutrients, Australia 1981-1982 Canberra: Australian Bureau of Statistics.

Beaton, G. H., Milner, J., McGuire, V., Feather, T. E. \& Little, J. A. (1983). American Journal of Clinical Nutrition 37, 986-995.

Conover, W. J. (1971). Practical Non-parametric Statistics, pp. 167-172. New York: Wiley.

Cook, J., Altman, D. G., Moore, D. M. C., Topp, S. G. \& Holland, W. W. (1973). British Journal of Preventive and Social Medicine 27, 91-99.

Darke, S. J., Disselduff, M. M. \& Try, G. P. (1980). British Journal of Nutrition 44, $243-252$.

Hitchcock, N. E. \& Gracey, M. (1980). Food and Nutrition Notes and Reviews 37, 115-121.

National Health and Medical Research Council (1971). Dietary Allowances for Use in Australia. Canberra: Australian Government Publishing Service.

Ohlson, M. A. \& Harper, L. J. (1976). Journal of the American Dietetic Association 69, 626-631.

Palmer, S. \& Bakshi, K. (1983). Journal of the National Cancer Institute 70, 1151-1170.

Samuelson, G. (1971). Acta Paediatrica Scandinavica 214 (Supplement), 5-44.

Samuelson, G., Grahnén, H. \& Arvidsson, E. (1971). American Journal of Clinical Nutrition 34, 1361-1373.

United States National Center for Health Statistics (1979). Dietary Intake Source Data 1971-1974. Hyattsville, Md.: US Department of Health, Education and Welfare.

van Schaik, T. F. S. M. \& Kenter, H. A. (1973). Voeding 33, 577-604.

Woodward, D. R. (1984). British Journal of Nutrition 52, 21-32.

Woodward, D. R., Lynch, P. P. Waters, M. J., Maclean, A. R., Ruddock, W. E., Rataj, J. W. \& Lemoh, J. N. (1981). Australian Paediatric Journal 17, 196-201. 